\title{
reparações e dívidas no entreguerras: as dificuldades político-econômicas da alemanha à luz das contribuições de hjalmar schacht ${ }^{\star}$
}

\section{reparations and debts in the interwar period: germany's political and economic difficulties in the light of hjalmar schacht's contributions}

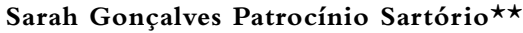 \\ Departamento de Economia, Universidade Federal do Espírito Santo,Vitória, ES, Brasil \\ Arthur Osvaldo Colombo $\star \star \star ~$ \\ Departamento de Economia, Universidade Federal do Espírito Santo,Vitória, ES, Brasil \\ Diego Gonçalves Favorato • \\ Departamento de Economia, Universidade Federal do Espírito Santo,Vitória, ES, Brasil
}

RESUMO

O artigo versa sobre a Alemanha e os principais desdobramentos dos pagamentos feitos por esta em reparação à Primeira Guerra Mundial (1914-1918). Esses desdobramentos serão reconstituídos à luz das contribuições do presidente do Banco Central alemão,
Abstract

This article brings a discussion about Germany and the main developments resulting from the reparation payments provided by that country, as a consequence of the World War I (1914-1918). Such developments will be reconstituted in light of the contributions

* Submissão: 06/07/2019; aprovação: 29/08/2020.

$\star \star$ Graduada em Economia pela Universidade Federal do Espírito Santo (UFES), mestre em Teoria Econômica pelo Programa de Pós-Graduação em Economia (PPGEco) da UFES. E-mail: sarahpatrocinio@hotmail.com. ORCID: <https:// orcid.org/0000-0003-0795-0140>.

$\star \star \star$ Graduado em Ciências Econômicas pela Universidade Federal de Uberlândia (UFU), mestre em Teoria Econômica pelo Programa de Pós-Graduação em Economia (PPGEco) da UFES. E-mail: arthur_colombao@hotmail.com. ORCID: $<$ https://orcid.org/0000-0002-1128-9140>.

- Graduado em Ciências Econômicas pela Universidade Federal Rural do Rio de Janeiro (UFRRJ), mestre em Teoria Econômica pelo Programa de Pós-Graduação em Economia (PPGEco) da UFES.E-mail: dfavorato@gmail.com. ORCID: < https://orcid.org/0000-0001-7106-5408>. 
Hjalmar Schacht. Inicialmente, apresentar-se-ão as perdas humanas e as dificuldades econômicas dos países europeus após esse conflito. A seguir, dar-se-á ênfase ao caso alemão, em razão das sanções do Tratado de Versalhes. Sobre este, observa-se ao longo do texto que Schacht, embora tenha participado ativamente dos Planos Dawes eYoung, lutou intransigentemente pelo fim das reparações. Ao final, discute-se sobre os motivos pelos quais esses planos foram infortúnios e demonstrar-se-ão as distintas mensuras acerca da quantia paga pela Alemanha aos vencedores da guerra.

Palavras-chave: Primeira Guerra Mundial. Tratado de Versalhes. Alemanha. Schacht. of Hjalmar Schacht, the president of German Central Bank. Initially, we will present the human loss and the economic difficulties faced by European countries after that conflict. Secondly, we will emphasize the German situation, due to the Treaty ofVersailles' sanctions. In this regard, it is noticeable throughout the text that Schacht fought uncompromisingly for the end of such reparations, although he actively participated in the Dawes and Young's Plans. Finally, we will discuss the reasons why such plans were unfortunate and demonstrate different measures taken in reference to the amount paid by Germany to the Winners of the War.

Keywords: First World War. Treaty of Versailles. Germany. Schacht.

\section{Introdução}

Em 11 de novembro de 1918 foi firmado o armistício entre alemães e o bloco dos Aliados ocidentais, dando fim ao mais sangrento conflito que o mundo havia conhecido, a Primeira Guerra Mundial (Mazzucchelli, 2009). Em junho do ano seguinte foi celebrado o Tratado de Paz, o qual se assenta sobre dois conceitos essenciais: a perda de território e a indenização financeira a ser paga pelo país tido como responsável pela guerra. A Alemanha tinha provocado tal guerra. Tão óbvia era essa afirmação aos olhos dos Aliados que nem sentiram a necessidade de fundamentar tal afirmação no texto do Tratado deVersalhes. ${ }^{1}$ Os termos do referido tratado não deixaram dúvidas sobre a pretensão do bloco dos Aliados em retardar o reerguimento econômico da Alemanha, o que a tornou, poucos anos depois, uma nação ansiosa por revanche (Keynes, 2002; Schacht, 1931).

No que segue, o presente artigo examina o impacto da Primeira Guerra Mundial (IGM) nas nações que participaram no conflito, em especial a Alemanha. Buscou-se demonstrar as várias consequências trazidas pela IGM; dentre as principais, pode-se citar as consequências

1 No decorrer do trabalho, leia-se "Aliados" como os vitoriosos na guerra (Estados Unidos, França, Reino Unido e os demais). 
sociais, econômicas e políticas, como o grande número de mortos durante o conflito e os elevados níveis de desemprego e instabilidade política e monetária. A fim de demonstrar empiricamente essas consequências, o artigo faz uma descrição dos principais pontos que foram celebrados em Versalhes sob a perspectiva de diferentes autores, descrevendo e analisando os valores a serem pagos pela Alemanha.

Visto isso, o artigo objetiva apresentar a concepção alemã acerca das reparações de guerra, bem como apresentar suas dificuldades político-financeiras para honrar esses pagamentos. Os livros de Hjalmar Schacht, presidente do Reichsbank no período entreguerras, são as principais referência neste texto, pois tal literatura narra as políticas e sanções econômicas sofridas pelos agentes externos e as políticas que esse economista implementou na Alemanha. ${ }^{2}$

Schacht foi figura chave na formulação da política econômica no período, participando ativamente nas questões referentes às reparações de guerra e à hiperinflação, uma vez que essas foram as principais causas de infortúnio dos alemães nos primeiros anos após a IGM. Ademais, cumpre ressaltar que a visão do banqueiro alemão é convergente com a obra As consequências econômicas da paz, de John Maynard Keynes, obra que obteve amplo sucesso e aceitação desde o seu lançamento (Favorato; Colombo, 2019). Com isso, nota-se que o prisma de interpretação de Schacht e Keynes vai de encontro ao dos países aliados, de modo que, dentre estes, a França era a nação que apresentava o posicionamento mais rigoroso em relação às reparações de guerra (Keynes, 2002). ${ }^{3}$

2 Horace Greeley Hjalmar Schacht nasceu na cidade de Tingleff, em Nordschleswig (atual região da Jutlândia, Dinamarca), no dia 22 de janeiro de 1877. Schacht concluiu os estudos na Johanneum em 1895 e em 1899 alcançou o título de Doutor em Filosofia Econômica. Entrou para o Dresdner Bank (1908-1923) e fez longa carreira como banqueiro, até que, vendo as dificuldades do seu país no pós-guerra, optou pela carreira pública, na qual comandou a política econômica alemã da República de Weimar até o III Reich (1924-1939). Embora não esteja dentro do escopo temporal deste trabalho, é importante mencionar que no ano de 1934 Hitler nomeou Schacht como General Plenipotenciário para a Economia de Guerra, cargo que surgia da fusão entre a presidência do Reichsbank e do Ministério da Economia (Schacht, 1999).

3 Utiliza-se, aqui, a versão traduzida da obra original de Keynes, As consequências econômicas da paz (1919) elaborada por Marcelo de Paiva Abreu (2002). 
No entanto, foram diversas as dificuldades apresentadas pela Alemanha para honrar essas reparações, uma vez que, além de limitações financeiras, a execução dos pagamentos também esbarrava em questões políticas (Abreu, 2002a). Outrossim, ocorrera que, a partir de 1929, o mundo passou por uma crise severa, o crash da bolsa de Nova York, circunstância esta que minou ainda mais as possibilidades na execução do que fora acordado em Versalhes. Assim, em meio às turbulências e contratempos da década de 1920, foram instaurados dois grandes planos econômicos, os planos Dawes eYoung, cujos objetivos eram pariformes: criar condições para a Alemanha honrar seus compromissos financeiros (Straumann, 2019; Mazzuchelli, 2009; Ahamed, 2009).

Isso posto, tem-se que, além dessa introdução, este artigo está organizado em outras quatro seções, seguidas pelas considerações finais e as referências bibliográficas. Na primeira seção, trata-se brevemente das perdas humanas ocosionadas pela IGM. A segunda seção, por sua vez, apresenta as cláusulas do Tratado de Versalhes e os obstáculos políticos e econômicos enfrentados pelas nações no período imediato após a IGM, com ênfase no caso alemão. A terceira seção descreve as distintas interpretações a sobre do Tratado de Versalhes, assim como as diferentes concepções dos países a respeito do mesmo. A terceira e a quarta seção trazem as interpretações de Schacht para as questões alemãs da época; na quarta seção, os planos Dawes e Young são abordados, destacando-se como as ações do então presidente do Reichsbank se tornaram mais determinantes no que tange ao desfecho do pagamento das reparações.

\section{Consequências sociais da Primeira Guerra Mundial}

A Primeira Guerra Mundial - chamada à época de Grande Guerra - marcou uma profunda ruptura entre o antes e o depois da história europeia e mundial (Hobsbawm, 1995).As principais potências europeias embarcaram numa guerra generalizada e dividiram-se em duas grandes alianças diplomáticas: a primeira, a Tríplice Aliança, era inicialmente composta pelo Império Alemão, Império Austro-Húngaro e Itália.Ainda no ano de 1914, o Império Otomano entra na guerra por meio de uma aliança germano-otomana; a segunda era a Tríplice Entente, constituída pelo Reino Unido, França e o Império Russo, em apoio à Sérvia. Mais 
tarde a Tríplice Entente recebeu a adesão dos Estados Unidos da América (Hobsbawm, 1988). ${ }^{4}$

É de suma importância esclarecer que em ambos os lados da contenda esperava-se que a guerra fosse de curta duração - cerca de quatro meses no máximo - de modo que todos pudessem passar o Natal com suas famílias. Todavia, as expectativas de que a guerra seria curta, edificante e até "divertida", deram lugar a um desagradável sentimento acerca da enormidade e da intratabilidade dos infindáveis combates. Sobre essa questão, Schacht (1967, p. 77, tradução nossa) faz uma comparação: "enquanto a guerra franco-prussiana de 1870 durou sete meses, a Primeira Guerra Mundial levou mais de cinquenta meses".

Nessa Grande Guerra, o Estado, a sociedade e a produção industrial voltam-se, exclusivamente, para sustentar o esforço de guerra; ou seja, é a junção dos meios nacionais com os avanços tecnológicos. Por esse motivo, a produção agrícola e industrial exigia uma plena consciência de organização e administração, pois a guerra era, na verdade, o maior empreendimento até então conhecido do homem. Queria-se, inclusive, que a escala de produção da guerra fosse planejada para operar nos tempos de paz, embora seja sabido que algumas indústrias, como a têxtil (que fabricava os uniformes militares), inevitavelmente sentiriam um impacto de queda na demanda maior que outros segmentos da indústria (Hobsbawm, 1995).

4 Mesmo antes da formação de ambos os blocos para o grande conflito bélico, é possível observar que existiam alguns acordos bilaterais entre as potências europeias, o que polarizou as disputas econômicas entre as nações. A formação inicial da Tríplice Aliança detinha um acordo de neutralidade que vigorava desde 1882, isto é, caso um dos países declarasse guerra os outros deveriam, ao menos, permanecer neutros. Algumas outras questões também estavam acordadas. Em um possível ataque da França aos italianos, de imediato austríacos e alemães deveriam apoiar a Itália. Ao passo que se os alemães sofressem um ataque por parte da França os italianos deveriam se unir em prol dos alemães. Além disso, se, eventualmente, duas nações europeias quaisquer entrassem em conflito com qualquer membro deste bloco, os outros integrantes deveriam dar suporte. Do lado da Tríplice Entende, em 1904, França e Inglaterra acordaram que os ingleses teriam direito de explorar a região do Egito, enquanto os franceses teriam seus interesses garantidos no Marrocos. Não obstante, Inglaterra e Rússia apresentavam interesses conflitantes, no que dizia respeito à exploração econômica do Oriente médio e Ásia Central. Com intermediação diplomática em 1907, essas diferenças foram postas de lado. Isso possibilitou, em um primeiro momento, a consolidação da Tríplice Entende (Araripe, 2006). 
No que toca aos aspectos da existência humana, observa-se que os terríveis acontecimentos entre 1914 e 1918 deixaram marcas cravadas nos homens, nas famílias, nas sociedades e nos Estados. As mortes, as privações e os traumas vividos causaram feridas profundas, de modo que o desejo de cicatrizar essas feridas suscitou em muitos a utopia de voltar aos tempos dourados da Belle Époque (Mazzucchelli, 2009).

Os números dessa Grande Guerra podem ser conferidos na Tabela 1, que aponta de maneira destacada o caso da França, que teve 78\% da Força Total Mobilizada (FTM) vitimada durante o conflito, o equivalente a mais de seis milhões de pessoas entre mortos, feridos, prisioneiros e desaparecidos. Desta FTM, 17\% foram mortos, cerca de 1,3 milhões de pessoas, o que corresponde a 3,4\% da sua população no ano de 1914 (Hastings, 2014).

Tabela 1 - Relação do total de vítimas da Grande Guerra por país

\begin{tabular}{l|c|c|c|c}
\hline \multicolumn{1}{c|}{ País } & $\begin{array}{c}\text { ForÇA Total } \\
\text { MobilizAdA (FTM) }\end{array}$ & $\begin{array}{c}\text { Total DE } \\
\text { vítimas }\end{array}$ & $\begin{array}{c}\text { Mortos } \\
\%\end{array}$ & $\begin{array}{c}\text { \% Vítimas } \\
\text { POR FTM }\end{array}$ \\
\hline França & 7.891 .000 & 6.178 .800 & $17 \%$ & $78 \%$ \\
\hline Império Austro-Húngaro & 9.000 .000 & 6.920 .000 & $12 \%$ & $77 \%$ \\
\hline Rússia & 15.798 .000 & 9.250 .000 & $11 \%$ & $59 \%$ \\
\hline Alemanha & 13.200 .000 & 7.405 .858 & $15 \%$ & $56 \%$ \\
\hline Império Otomano & 2.998 .000 & 1.454 .000 & $27 \%$ & $48 \%$ \\
\hline Império Britânico e Domínios & 8.904 .467 & 3.190 .235 & $10 \%$ & $36 \%$ \\
\hline Total & 57.971 .467 & 34.398 .893 & $15 \%$ & $60 \%$ \\
\hline
\end{tabular}

Fonte: British Council (2014, p. 24).

Nota: dados adaptados e ranqueados pelos autores pelo maior percentual (\%) de vítimas por FTM. Entende-se por vítima: mortos, feridos, prisioneiros e desaparecidos. O quadro se ateve a apresentar os dados dos principais países de cada bloco do conflito:Tríplice Aliança e Tríplice Entente (Aliados).

Essa tabela apresenta com alguma exatidão o número de militares envolvidos na IGM, porém é importante frisar que é ainda mais dificil estimar com precisão o número de mortes de civis, pois muitos padeceram por desnutrição e doenças relacionadas às condições insalubres do ambiente de guerra. Números mais precisos ainda estão em discussão, visto que existem diferentes definições e parâmetros que podem ser utilizados como medida. Isso porque, enquanto alguns países conseguiram manter em segurança um vasto acervo de registros de fontes oficiais, 
outros não mantiveram praticamente nenhum. Ainda assim, a estimativa de mortos em nível global, de quase 10 milhões de militares e 6,5 milhões de civis, dá alguma ideia da magnitude da catástrofe (British Council, 2014).

Por fim, tem-se que a Grande Guerra foi marcada pela derrota da Tríplice Aliança e, portanto, também a derrota da Alemanha. As mudanças foram drásticas, dinastias seculares e impérios, como o Alemão, o Austro-Húngaro e o Turco, foram varridos do mapa, dando lugar a novos países. Dessa maneira, o mapa-múndi foi redesenhado e a Europa perdeu a exclusividade dos assuntos geopolíticos internacionais. Destarte, abriu-se uma época de grandes transformações, onde "mudar o mundo" havia deixado de ser apenas uma expressão retórica, e a prática revolucionária estava na ordem do dia, a começar pelo exemplo da Revolução Russa, em 1917 (Araújo, 2009).

\section{Consequências político-econômicas da Grande Guerra: o Tratado de Versalhes e suas incumbências para a Alemanha}

Em 1919 as forças aliadas que venceram a IGM realizaram uma Conferência de Paz na cidade de Versalhes, na França, para tratar das estratégias que garantiriam a paz no continente europeu. Com o passar dos dias, a Conferência foi relegando a garantia da paz a um plano secundário, e foi se revelando uma reunião cujo fim era apenas estipular quanto a Alemanha deveria pagar pelas perdas decorrentes da Grande Guerra. O resultado da Conferência ficou exposto no Tratado de Versalhes. As pressões do tempo tornaram-se tão agudas que ele foi, ao final, lançado como uma grande enxurrada, porque, apesar do Tratado ter sido elaborado por um comitê internacional, este não fora devidamente coordenado, em virtude das diferentes opiniões e posicionamentos das nações vencedoras (Couto; Hackl, 2007). Esse documento foi apresentado aos alemães em uma tensa cerimônia no Palácio de Versalhes no dia 7 de maio de 1919. Todavia, suspeitava-se que poucos haviam lido o Tratado de Paz na íntegra, e por isso acreditava-se que ninguém estava muito certo do conteúdo deste. Assim, essencialmente sob a forma de um ultimato, o Tratado foi assinado pelos Aliados e pelos represen- 
tantes alemães em 28 de junho de 1919, exatos cinco anos após o estopim do conflito (Marks, 2003).

Segundo Joaquim Couto e Gilberto Hackl (2007), dentre as 440 cláusulas das mais de 200 páginas do tratado, as imposições que trouxeram maiores consequências à economia alemã foram:

(a) o pagamento de reparações de guerra aos países vencedores, cujo valor seria posteriormente definido; b) a destruição de todos os armamentos e equipamentos de guerra alemães; (c) a proibição de edificar qualquer espécie de construção militar na região das margens do rio Reno; (d) a perda da região mineradora do Sarre para a França, como compensação aos prejuízos causados durante o conflito; (e) a entrega de oficiais alemães nominalmente escolhidos para julgamento; (f) a imposição à Alemanha de toda a responsabilidade moral pela guerra; (g) a perda dos territórios do Togo (para a Grã-Bretanha e a França), de Camarões (para a França), da Tanzânia e Namíbia (para a Grã-Bretanha), de Ruanda-Burundi (para a Bélgica), das Ilhas Marianas e Ilhas Carolinas (para o Japão), do Arquipélago de Bismarck (para a Austrália), além da anexação da região da Alsácia-Lorena pela França e da anexação das regiões germânicas da Pomerânia, Prússia Ocidental e Alta Silésia pela Polônia. (Couto; Hackl, 2007, p. 314-315)

Observa-se que o empenho dos Aliados estava em assegurar que a Alemanha, depois da guerra, não tivesse mais recursos industriais ou militares para iniciar outro conflito. Entretanto, é interessante notar o paradoxo que são essas imposições feitas à Alemanha, pois para assegurar que as dívidas de guerra fossem pagas seria preciso promover o desenvolvimento e prosperidade do país, correndo um grande risco de que, uma vez próspera, ela não mais aceitaria ser explorada durante muito mais tempo pelos seus vencedores (Becker, 2011).

Nas palavras de Schacht (1967), a alegação dos vencedores de que os perdedores deveriam compensar os gastos que estes primeiros tiveram com a guerra era algo desproporcional à realidade da Alemanha, visto que esta havia gasto todas as suas reservas de ouro durante o curso da guerra e, portanto, considerava-se incapaz de pagar os custos estimados:

O custo total da Primeira Guerra Mundial foi estimado na época em 850 bilhões de marcos de ouro. A participação da Alemanha nessa perda foi estimada em 150 bilhões. Os aliados, portanto, visavam à restituição de 700 
bilhões, que deveriam ser pagos pela Alemanha. $\mathrm{Na}$ verdade, a primeira exigência do ministro da economia francês, Klotz, foi de 420 bilhões. Entretanto, era um absurdo aceitar tais somas em moeda alemã [...] pois o marco alemão tinha poder de compra apenas na Alemanha [...]. Os vencedores então voltaram aos métodos de compensação da história antiga. Todos os bens móveis que poderiam ser úteis foram levados [...].A Alemanha poderia fornecer carvão, potássio, navios, vagões e locomotivas, produtos químicos, aço e outros produtos industriais. É claro que isso também logo despertaria oposição nos países vitoriosos, cujas indústrias queriam fabricar e vender essas coisas por si mesmas. (Schacht, 1967, p. 91-92, tradução nossa)

Para a França parecia existir apenas uma única doutrina econômica na cartilha das finanças: a obtenção dos pagamentos de reparação da Alemanha. Contudo, sem o apoio de seus aliados, especialmente dos Estados Unidos e da Inglaterra, a França, a rigor, não detinha pujança material e militar suficiente para impor a sua vontade (Arthmar, 2011). Diferentemente da França, os Estados Unidos tinham a convicção de que "a recuperação econômica da Alemanha consistia em fator essencial ao progresso de uma Europa pacificada, o que significava, no plano prático, uma maior moderação nas pretensões francesas de extrair o máximo de reparações do inimigo" (Arthmar, 2002, p. 108). Nota-se que o objetivo americano era de conceber uma paz mais justa e não punitiva a partir do Tratado deVersalhes, criando, ainda que ao seu modo protecionista e isolacionista quanto às políticas internacionais, uma nova ordem mundial baseada na Liga das Nações. ${ }^{5}$ Assim, de maneira gradual e dentro da ordem existente, as nações desfavorecidas seriam, por etapas, incorporadas a um sistema cada vez mais próspero e equilibrado pautado no padrão-ouro (Costigliola, 1984).

Os britânicos, por sua vez, estavam com o pensamento alinhado com os americanos, pois reconheciam que a recuperação do Estado Alemão era importante para o comércio internacional, sobretudo para reanimar a sua economia interna. Afinal, a Grã-Bretanha queria evitar contrariar

5 A Liga das Nações foi criada logo após o final da guerra e tinha os países Aliados como seus principais membros. O principal objetivo era evitar outro grande conflito armado, tendo em vista a grande catástrofe que foi a IGM. Porém, enquanto a instituição tinha como objetivo a reparação mundial pós-guerra, França e Inglaterra acabam utilizando-a para fins particulares, fadando ao fracasso com a chegada da Segunda Guerra Mundial. 
desnecessariamente os Estados Unidos, a fim de ter uma política comum com eles - política "anglo-americana"-,já que eles são o único país com quem nutria um relacionamento estratégico especial, principalmente no período entre 1919-1920, quando sofria aflições e agruras por indefinição em congregar-se mais rapidamente ao sistema de padrão-ouro (Ferris, 1989). Também é importante mencionar que a Grã-Bretanha buscava recuperar o seu nível de exportações à Europa, e que por isso havia um receio de a Alemanha fazer uma política de exportação mais agressiva, o que geraria uma intensa competição pelos mercados continentais, mas sabe-se que isso só se estabeleceria caso a Alemanha fosse coagida a obter expressivos superávits comerciais a fim de angariar as divisas necessárias ao pagamento das reparações; e por isso a Inglaterra tentava neutralizar os ânimos da potência vizinha, a França (Arthmar, 2002; Nogueira, 2010).

Segundo John Ferris (1989), ora afirmava-se que o poderio francês era essencial para a estabilidade europeia, ora afirmava-se que apenas uma aliança com a França poderia garantir a segurança britânica contra a Alemanha. Jean-Jacques Becker (2011), no entanto, afirmava que o essencial era, na verdade, duas coisas: os comportamentos da opinião francesa e da opinião norte-americana:

O comportamento da opinião francesa, pois foi a França que suportou o principal peso da guerra, e o da opinião norte-americana, porque sem eles os Aliados não teriam ganho a guerra. Em 1919 a opinião francesa estava mais preocupada em retomar uma vida normal, [...] em livrar-se da "vida cara", da crise econômica, das greves, do que discorrer sobre vantagens e falhas de um tratado que evidentemente não era o desejado pela França, mas o imposto pelos anglo-saxões. (Becker, 2011, p. 175)

Ainda que na visão alemã o Tratado de Versalhes seja considerado demasiadamente rigoroso, é necessário ressaltar que boa parte do território ao nordeste da França havia sido destruído durante a guerra. A Alemanha se apossou de fábricas e até mesmo do gado de origem francesa. Ademais, quando bateram em retirada, tropas alemãs inundaram minas de carvão francesas justamente com o intuito de enfraquecer o inimigo. Com isso, é possível perceber que a França enfrentava dois grandes problemas, as dívidas internas e a reconstrução, enquanto a Ale- 
manha tinha necessidade de se preocupar apenas com o primeiro (Mouré; Martin, 2002).

Da mesma maneira, também é necessário ressaltar que os aliados buscavam com o Tratado de Versalhes elaborar uma agenda de pacificação, enquanto os alemães apresentavam um pensamento, no mínimo, equivocado, de que seriam tratados como iguais durante as negociações desse documento. Uma vez que não se concretizou tal ilusão alemã, as opiniões que nutriam o ódio e as imposições feitas emVersalhes começaram a se formular. Isto é, a percepção errada dos alemães ajuda a explicar o clima de revanchismo que foi gerado com o Tratado. Porém, é curioso notar que, embora Keynes (2002) insista em apontar que o objetivo da França com as reparações era, a todo custo, enfraquecer a Alemanha, as cláusulas consideradas as mais duras (231 e 232) foram, na verdade, de autoria americana e não francesa. No entanto, cumpre observar que as carências da França em parte contaram com o apoio anglo-saxão. Além disso, é plausível considerar que as reparações atenderam parte dos interesses britânicos ao conseguirem alcançar a segurança naval e reduzirem o aparato naval alemão (estipulado no Tratado), bem como quando inseriram no documento pensões e subsídios em indenizações, a fim de beneficiar os contribuintes britânicos. ${ }^{6}$ Também é interessante enfatizar que a Inglaterra e os Estados Unidos esperavam reintegrar uma Alemanha reconciliada, mas com seu "status de nação" reduzido. Justamente por isso, ajudaram a formular a parte do Tratado referente à Renânia, atendendo, assim, as requisições francesas (Boemeke; Feldman; Glaser, 1998). Além das mortes, a guerra também demonstrou a supremacia do poder financeiro como base do poder econômico, sendo este a base para

6 É interessante citar a participação de um importante membro da comissão britânica presente na elaboração do Tratado de Versalhes, Sir Robert Cecil. Um dos papéis de Cecil era fazer com que a Alemanha reconhecesse que foi a culpada de iniciar o conflito, mas ao mesmo tempo não ser execrada por isso. Dessa forma, Cecil, junto com Keynes, criaram um plano econômico de conteúdo moderado para ser apresentado aos representantes do grupo dos Aliados e para a Alemanha. Embora a proposta formulada por Keynes e Cecil estivesse amplamente fundamentada, para a frustração dos dois ela fora rejeitada. Cecil pediu para seu companheiro de delegação, Keynes, que o ajudasse a reformular o plano econômico para ser reapresentado ao Conselho, porém este negou, afirmando que o Tratado caminhava para um rumo que não buscava a reconstrução da Europa, mas sim lesar ao máximo a Alemanha. Mesmo com os esforços de Cecil, o Conselho optou por impor reparações pesadas à economia alemã do pós-guerra (Dehne, 2019). 
o poder militar. De um modo geral, os governos consideravam as finanças como um elemento mais importante de poder do que a força armada. Um exemplo disso é que, ao final da guerra, o crédito fora considerado a fonte de todo poder econômico de uma nação. A ideia era: "se o crédito realizou tanto durante um período de destruição, o que não poderia realizar então em um período de reconstrução?” (Ferris, 1989, p. 34, tradução nossa). A resposta não era simples, e os caminhos eram diversos. A França, por exemplo, pegou empréstimos não só para financiar a reconstrução das áreas devastadas, mas também para realizar muitas outras políticas nacionais, como repassar esses créditos aos seus estados em uma escala muito ampliada. A Grã-Bretanha, por sua vez, escolheu o caminho mais doloroso: escolheu liquidar os dividendos existentes antes de pegar mais crédito, e por isso conseguiu atingir uma posição financeira de solvência básica. A política de crédito alemã, por sua vez, assemelha-se mais com a da França do que com a da Grã-Bretanha, devido ao financiamento interno, as obrigações das reparações e a inflação da moeda (Moulton; Lewis, 1926).

A intenção da Alemanha em pegar uma série de empréstimos internacionais era de indenizar os governos aliados, uma vez que assim "preservaria os recursos da nação, evitaria a tributação dos cidadãos alemães e exigiria uma reformulação da escala de pagamentos em condições mais aceitáveis para os bancos norte-americanos comprometidos com o país" (Arthmar, 2002, p. 107). Entretanto, o que ninguém sequer imaginaria era que os dias de amargura não havia ainda se encerrado. Pouco mais de um ano após o Armistício, em maio de 1929, a economia internacional sofreria um grande abalo: o colapso das bolsas de valores de Nova York. As vendas e a produção ao redor do mundo, em todos os ramos do atacado e do varejo, em especial na América do Norte e na Europa, despencaram assustadoramente, roubando de uma hora para outra o sustento de milhões de trabalhadores remessados ao desemprego. Isso ocorreu, dentre outros motivos, porque as vendas de armas e munições foram quase que instantaneamente substituídas por uma grande demanda por alimentos, matérias-primas e bens de capital, com fins de socorrer as populações famintas e atender às necessidades de reconstrução das nações europeias. 
Tabela 2 - O endividamento interaliado referente ao ano de 1923 (valores nominais em dólares $-00,00$ omitidos)

\begin{tabular}{l|c|r|r|r|r|r}
\hline \multicolumn{7}{c}{ CREDORES } \\
\hline Devedores & Grã-Bretanha & França & \multicolumn{1}{c}{ Itália } & \multicolumn{1}{l}{ Rússia } & \multicolumn{1}{l}{ EUA } & \multicolumn{1}{l}{ Total } \\
\hline Grã-Bretanha & - & 359.8 & 133.8 & 1.265 .2 & 4.661 .0 & 6.419 .8 \\
\hline França & 2.927 .6 & - & 96.6 & - & 3.990 .7 & 7.014 .9 \\
\hline Itália & 2.568 .6 & 163.9 & - & - & 2.015 .0 & 4.747 .5 \\
\hline Rússia & 4.322 .0 & 1.165 .7 & 7.2 & - & 241.9 & 5.735 .9 \\
\hline Estados Unidos & - & - & 2.8 & - & - & 2.8 \\
\hline Total & 9.818 .2 & 1.689 .4 & 240.4 & 1.265 .2 & 10.908 .6 & 23.921 .8 \\
\hline
\end{tabular}

Fonte: Fisk (1924, p. 9).

Nota: dados adaptados pelos autores, apresentando apenas os principais países aliados.

Na França, a depreciação do franco exigiu taxas de juros cada vez mais elevadas para a rolagem da dívida pública, comprometendo a execução financeira do Tesouro de forma irremediável. Emile Moreau, diretor geral do Banco da França (1926-1930), permaneceu inflexível em sua recusa de intervir no mercado cambial, pois estava temeroso de que, ao frear a valorização da moeda, viesse a ser deflagrada uma nova investida dos especuladores em favor da desvalorização. Se essa situação se concretizasse, o Banco da França não teria reservas suficientes para estancar o processo e, com vistas a superar o problema, Moreau teria de recorrer aos empréstimos externos. Todavia, essa solução estava obstruída pela falta de aprovação dos acordos sobre as dívidas interaliadas, expressas na Tabela 2 (Arthmar, 2011).

É importante destacar que o total desta tabela (\$23.921.800) representa $85 \%$ do total apresentando ( $\$ 28.261 .100)$, utilizando os montantes de apenas cinco países. Essa diferença (\$4.239.300) entre os totais foi esmiuçada pelo autor na contabilidade dos empréstimos de outros 20 países, além dos países de domínio do Império Britânico. No ano seguinte, 1924, a dívida da França com os Estados Unidos somava 3,7 bilhões de dólares e 627 milhões de libras com a Inglaterra. No entendimento da França, tais valores sequer deveriam ser cobrados por se tratarem de parte do esforço de guerra aliado. Essa posição, porém, era contrária ao entendimento dos Estados Unidos, que impuseram um embargo financeiro ao país até a resolução definitiva da questão, ou seja, até que fossem realizados os devidos pagamentos das dívidas (Bonnefous, 1960). 
No entanto, o governo dos Estados Unidos estava tentando encerrar suas atividades de empréstimo, e para isso ele queria forçar a Grã-Bretanha, sua maior devedora, a combinar os acertos dos créditos cedidos. Os britânicos, preocupados com o seu equilíbrio na balança de pagamentos, não estavam dispostos a aumentar o seu próprio endividamento através da concessão de créditos abertos a terceiros. Isso posto, nota-se que, no que toca ao crítico caso francês, não havia esperança de que o Congresso americano aprovaria o cancelamento dos empréstimos ou qualquer ação que reduza seu valor. Não obstante, essa recusa americana de cooperação fez com que os franceses se voltassem novamente para a questão das reparações de guerra a serem pagas pela Alemanha (Orde, 1990). Segundo Jean-Jacques Becker (2011), a morosidade nos pagamentos por parte da Alemanha estava assentada em dois principais motivos: porque os alemães incrementavam meios para não pagar (nem o mínimo possível) e em virtude das tentativas da França de se apossar "indevidamente" do território alemão às margens do rio Reno.

Em defesa da Alemanha, Schacht afirma que a política financeira do país se adaptou totalmente à guerra, de modo que as exigências econômicas se tornaram constantes e crescentes. Outrossim, cumpre observar que os países beligerantes que participaram da IGM saíram do conflito de maneira muito semelhante: com problemas fiscais e monetários.Ademais, o economista também acredita que "os enormes custos incorridos pela Primeira Guerra Mundial [...] podem muito bem ter sido a razão para as proporções astronômicas em que os Aliados avaliaram o pagamento de danos de guerra" (Schacht, 1956, p. 126, tradução nossa).

Desse modo, após as informações apresentadas ao longo desta seção, pode-se concluir que, diferentemente do que é comumente acreditado, a IGM não cessou em virtude das batalhas, das greves ou das revoltas civis. $\mathrm{Na}$ verdade, foi a perene fuga dos recursos econômicos das nações beligerantes - em especial a Grã-Bretanha, França e Alemanha - a responsável pelo colapso da IGM (Schacht, 1956). Por último, Schacht (1967) escreve que a IGM deixou duas grandes lições para futuros belicistas: em primeiro lugar, é necessário possuir uma quantidade de matérias-primas e alimentos suficiente para cobrir todas as necessidades durante a guerra, ou pelo menos pela duração de tempo pela qual ela está prevista. Em segundo lugar, aqueles que estão em guerra devem estar preparados, se necessário, para dedicar toda a renda nacional ao 
esforço de guerra, e que os sacrifícios necessários devem ser distribuídos justa e uniformemente.

\section{Tratado de Versalhes: concepção dos termos e condescendência dos pagamentos}

Há ao menos duas interpretações principais para o Tratado de Versalhes: a de Sally Marks em seu livro A ilusão da paz (2003) e a de John Maynard Keynes em seu livro As consequências econômicas da paz (1919). A interpretação de Marks (2003) aponta algumas questões fantasiosas acerca do Tratado; a autora descreve o que os alemães pensavam do Tratado e como eles convenceram a todos de que era abusivo. Keynes, por sua vez, é condolente ao sentimento alemão e enxerga o documento de forma exageradamente perversa. Nas palavras do autor:

O Tratado de Paz não contém qualquer disposição orientada para a reabilitação econômica da Europa - nada que transforme as Potências Centrais derrotadas em bons vizinhos, nada que permita dar estabilidade aos novos Estados europeus, nada para salvar a Rússia; não promove de nenhuma forma um pacto de solidariedade econômica entre os próprios aliados. Em Paris nada se fez para restaurar as finanças desordenadas da França e da Itália, ou para ajustar os sistemas do Velho e do Novo Mundo. (Keynes, 2002, p. 157)

A concepção de Keynes municiou os argumentos dos defensores da teoria de que o Tratado de Versalhes, como foi estabelecido, era na verdade uma espécie de "paz cartaginesa" e, como consequência, traria ao invés de paz, apenas sentimentos de ódio e motivações para uma futura revanche por parte dos alemães (Favorato; Colombo, 2019). Abreu (2002b) aponta que a obra de Keynes é extraordinária justamente por abarcar questões políticas, técnicas e de relações internacionais, tanto antes como após 1914, com o intuito de auxiliar na formação de uma paz que proporcionasse uma recuperação para a Europa que havia sido destruída fisica e financeiramente com a guerra. No entanto, o que foi alcançado emVersalhes era, no mínimo, insatisfatório na visão de Keynes: 
O Tratado nasceu de suas disparidades e fraquezas, filho dos menos valiosos atributos de seus pais: sem nobreza, sem moralidade, sem intelecto [...]. Na sua análise do Tratado deVersalhes, Keynes considera separadamente as suas condições gerais e as reparações. Quanto ao tratado em geral, Keynes analisa uma longa lista de cláusulas que considerava indevidamente lesivas aos interesses alemães que vão desde o tratamento da propriedade privada de cidadãos alemães nas ex-colônias e na Alsácia-Lorena até a interferência na operação das ferrovias alemãs passando pelo volume de entregas de carvão à França, considerado inviável. Keynes questionou acertadamente as avaliações francesas sobre os danos provocados pela guerra que eram cerca de seis vezes maiores do que o razoável. (Abreu, 2002b, p. 8-9)

É oportuno mencionar que ao longo desta seção também será apesentada a visão de Schacht. Trata-se de uma ótica alemã acerca dos desdobramentos do Tratado onde se utilizará, dentre outras literaturas, o livro O fim das reparações (1931). Cumpre mencionar que a visão desse autor possui diversas similitudes com a visão keynesiana, haja vista que, em vários momentos, tanto Keynes como Schacht, advertiram que a busca da paz deveria passar pelo fortalecimento e reconstrução da Alemanha, e não o contrário (Mazzucchelli, 2009):

É razoável elucidar que o livro de Keynes influenciou análises e as atitudes do banqueiro alemão Hjalmar Schacht, que tinha por objetivo acabar com as crises enfrentadas pela Alemanha no pós-guerra. Schacht considerava que o Tratado como foi proposto tornava impossível o pagamento por parte da Alemanha das reparações de guerra, principalmente levando em consideração o período conturbado vivido pela nação no pós-guerra. Schacht durante várias vezes auxiliou nas negociações das cifras que envolviam as reparações de guerra, inclusive participando de reuniões com representantes franceses em 1921 para explicar qual era a situação financeira alemã naquele período, comprovando que não havia possibilidade da Alemanha honrar com o valor imposto inicialmente no Tratado. Em 1923 fez o mesmo em uma reunião com representantes da Inglaterra, afirmando que as reparações nas presentes cifras acentuariam o problema da inflação vivido pelo povo alemão. (Favorato; Colombo, 2019, p. 16)

Para Schacht o Tratado de Versalhes exigiu da Alemanha não apenas compensações pelos danos causados à população civil dos Aliados e suas propriedades, mas também impôs ao país uma enorme indenização, 
astuciosamente escondida sob a palavra "reparação", causando à Alemanha uma vergonha moral, de forma que a imoralidade do Tratado foi reconhecida desde o início, não apenas dentro do país, mas também no exterior, por vários países membros do grupo dos Aliados, em especial pelos Estados Unidos. Na concepção desse economista, é preciso abandonar a ótica do Tratado de Versalhes que enxerga a Alemanha e os seus aliados como os únicos responsáveis pela guerra.Tal concepção, segundo ele, baseou-se em evidências incompletas e nem sempre sólidas (Schacht, 1931). Essa premissa de evidências incompletas questionada por Schacht está calcada no artigo 231 do Tratado, o qual complementa e justifica o artigo 232. São elas:

231 - Os governos aliados e associados declaram e a Alemanha reconhece que ela e seus aliados são responsáveis por todas as perdas e todos os danos sofridos pelos governos aliados e associados e seus cidadãos em consequência da guerra que lhes foi imposta pela agressão da Alemanha e de seus aliados;

232 - A Alemanha se compromete a reparar todos os danos causados à população civil das potências aliadas e a seus bens. (Becker, 2011, p. 62)

Esses artigos estão entre as mais famosas cláusulas do Tratado, pois são onde mais se concentram as críticas de prós e contras do documento. Por exemplo, no entendimento keynesiano, o artigo 231 impõe à Alemanha duras sanções e reparações despropositadas (Mazzucchelli, 2009), já para Marks (2003), esse artigo foi definido de maneira pouco precisa, o que levou para a história uma ideia de que houve muita hostilidade com o povo alemão. Para a autora essa ideia não passa de um truque, "onde os países vitoriosos poderiam assegurar ao eleitorado que ganhariam muito mais do que foi pedido, e os políticos alemães poderiam angariar votos ao lutar contra estas supostas demandas de ordem astronômicas" (Marks, 2003, p. 14, tradução nossa).

Sobre o Artigo 232, Marks diz ainda que este restringe o artigo anterior (231), de modo que a responsabilidade dos civis está calçada no comprometimento com os reparos da guerra, ou seja, com as indenizações. Sobre estas, o Tratado de Versalhes condenou a Alemanha a pagar de imediato 20 bilhões de marcos-ouro até que a responsabilidade total do país pudesse ser efetivamente calculada pela Comissão de Reparação, a 
qual era composta por membros do bloco dos países aliados. Essa quantia inicial poderia ser paga em dinheiro e em produtos diversos, como carvão, madeira e produtos químicos. Durante os anos em que não se tinha em mão o valor fixado pela comissão, a Alemanha teve margem para propagar reclamações sobre um cheque que ainda estava em branco. ${ }^{7}$ Além disso, o país não cumpriu com os pagamentos previamente estipulados, transferindo apenas 8 bilhões de marcos-ouro no período entre maio de 1919 e maio de 1921. Um valor muito abaixo do pagamento interino estabelecido (Marks, 2003).

Em defesa da Alemanha, Keynes (2002) escreve que esses 8 bilhões correspondem a um alto percentual da renda nacional alemã, cerca de $20 \%$ da renda do ano de 1921. Ocorre que, dois anos após a assinatura do Tratado de Versalhes, em 27 de abril de 1921, a Comissão de Reparação anunciou sua decisão: a Alemanha deveria pagar um montante de 132 bilhões de marcos-ouro. ${ }^{8} \mathrm{~A}$ distribuição desses pagamentos, conforme relatado oficialmente pela comissão, seria dividido entre as várias potências aliadas e associadas. $\mathrm{O}$ rateio, se feito proporcionalmente, dar-se-ia da seguinte maneira: França, 52\%; Império Britânico, 22\%; Itália, 10\%; Bélgica 8\%; e outros, 8\% (Fisk, 1924).

A preocupação francesa era justificável, pois seria ela quem mais se sacrificaria se houvesse uma redução do valor das reparações, dado o montante a ser recebido (Maier, 1988; Lewis, 2003). Todavia, os reclames franceses não foram considerados, e em 5 de maio do mesmo ano houve uma flexibilização desse montante estipulado pela Comissão de

7 Alguns números discutidos na conferência deVersalhes foram tão astronômicos, que chegaram a ser 16 vezes maior que o montante definido em 1921 (Marks, 2003).

$\mathrm{Na}$ verdade, esse valor simbolizava um compromisso. Tratava-se de um montante quatro vezes menor do que o pretendido pelos franceses, mas ainda assim era uma quantia aceitável (Maier, 1988, p. 241, tradução nossa). Entretanto, há divergência entre os autores quanto ao valor das cifras impostas à Alemanha, pois estes utilizaram diferentes taxas de conversão. De acordo com Hackl (2005), para Bubholz (2002), eram 132 bilhões de marcos-ouro; já para Bresciani-Turroni (1989), eram 136 bilhões de marcos-ouro; e Reis (2005) calculava 90 bilhões de marcos-ouro. Dessa maneira, este trabalho seguirá à luz das referências de Schacht, que em sua autobiografia reconhece que há discordância de valores, sendo a primeira cifra tornada pública a do ministro francês das finanças, Klotz, de 450 bilhões de marcos-ouro. Mais adiante Schacht diz que foi no Ultimato de Londres, no ano de 1921, que "as reparações foram fixadas definitivamente em 120 bilhões de marcos-ouro" (Schacht, 1999 , p. 230, tradução nossa). 
Reparação. Nesse episódio, a França fez oposição à flexibilização dos pagamentos, enquanto os delegados belgas e italianos concordaram com os britânicos que Berlim simplesmente não poderia pagar a dívida inicialmente estipulada, visto que culminava em uma "impossível" parcela de 8 bilhões de marcos-ouro a ser pago por ano. Isso irritou ainda mais a França, porque dias antes ela havia concordado em deixar a Bélgica receber o primeiro bilhão de marcos a ser pago pela Alemanha (Maier, 1988).

Essa flexibilização ocorreu no chamado Ultimato de Londres, e fez cair em mais da metade o então cronograma de pagamentos, tornando os 132 bilhões marcos-ouro apenas um cálculo burocrático. No novo acordo, ficou estabelecido que a dívida alemã seria reduzida para 50 bilhões de marcos-ouro (já incluindo os 12 bilhões não pagos dos primeiros 20 bilhões), a ser paga com base em um complexo cronograma de depósito de dinheiro e entrega de mercadorias, como o carvão, com vistas a pagar o juros e amortizações desses 50 bilhões de marcos-ouro (Marks, 2003). Nesse novo acordo, diante da unânime ameaça dos países aliados em invadir oVale do Ruhr caso não aceitasse os termos da agenda, a Alemanha se comprometeu a efetuar um pagamento de 2 bilhões de marcos-ouro no início de cada ano. ${ }^{9}$ Uma quantia fixa que, somada a um pagamento de quantia variável, iria aumentar o montante gradativamente até chegar a cifra de 6 bilhões de marcos-ouro por ano, totalizando 120 bilhões de marcos-ouro ao final do período, que seria de mais ou menos 40 anos (Schacht, 1999). Charles Maier (1988) explica que o novo total foi calculado da seguinte forma:

Berlim foi inicialmente obrigada a pagar os juros e amortizações dos 50 bilhões de marcos-ouro, os chamados bônus "A" e "B", pagando uma anuidade fixa de 2 bilhões de marcos-ouro, mais um pagamento variável equivalente em valor a $26 \%$ das exportações alemãs. Somente quando os lucros do comércio exterior alemão aumentarem o suficiente para amortizar os títulos "A" e "B", bem como pagar juros sobre os 82 bilhões de

9 Esta ocupação imediata doVale do Ruhr para forçar a Alemanha a produzir um plano de pagamentos trata-se de uma sugestão francesa feita na Conferência de Hythe, na Inglaterra, no dia 24 de abril de 1921, poucos dias antes do anúncio oficial da Comissão de Reparação. Na ocasião os ingleses então intervieram, dizendo que o Tratado deVersalhes só permitia a ocupação do Ruhr como uma espécie de "sanção" por inadimplência, não como meio de pressão (Maier, 1988; Lewis, 2003). 
marcos-ouro restantes, é que entraria em cena a emissão das obrigações dos títulos "C". Entretanto, muitos especialistas achavam que os títulos "C" eram um compromisso falso, projetado para apaziguar aqueles que ainda insistiam em um grande total. Mesmo que essas projeções estivessem corretas, a Alemanha não iria flutuar os títulos " $\mathrm{C}$ " antes do final da década. Isso significou a redução do valor presente da dívida das reparações para 108 bilhões de marcos-ouro. (Maier, 1988, p. 242, tradução nossa)

Mesmo com a flexibilização proposta na Conferência de Londres (1921), a Alemanha alegava que eram "pagamentos economicamente impossíveis e socialmente intoleráveis" (Schacht, 1931, p. 20, tradução nossa). Isso porque os pagamentos anuais fixados na conferência correspondiam a $10 \%$ da renda nacional alemã, e para que essa transferência fosse exequível, o saldo da balança comercial da Alemanha deveria ser o equivalente a 80\% das exportações em 1920-1921. Entretanto, o país enfrentava competição direta com as exportações dos antigos inimigos, o que, na concepção de Keynes (2002), inviabilizava política e economicamente o pagamento das reparações. Marks (2003) vai de encontro a esse pensamento keynesiano, e diz que o pagamento das reparações era, sim, viável economicamente, mas não politicamente, uma vez que se tratava de um período de sérias perturbações internas (1923-1924), a exemplo da latente hiperinflação alemã. ${ }^{10}$ Por esse motivo, houve a

10 A chamada era da inflação na Alemanha são os anos compreendidos entre 1920 e 1924. Tratar da era da inflação é tratar do bloqueio da entrada de alimentos no país, mas também da mortalidade infantil crescente; é tratar da entrega de bens a potências estrangeiras, mas também da inexistência de direitos políticos e do crescimento da criminalidade; é tratar do empobrecimento da pequena, média e alta burguesias, mas também da revolução social (Schacht,1967). Foi para colocar fim à hiperinflação que Schacht se tornou comissário de moeda e presidente do Reichsbank em 1923. Porém, para isso o economista precisou vencer dois grandes inimigos da estabilização monetária: o mercado paralelo e o dinheiro de emergência (Notgeld), sendo este último emitido tanto pelo setor público quanto pelas empresas privadas. Dessa forma, Schacht elaborou seu plano de ação baseado em três procedimentos: a) rejeição do dinheiro de emergência pelo Reichsbank; b) implementação do Rentenmark como meio de pagamento legal; c) por fim, a especulação contra o câmbio oficial do Reichsbank. Cumpre destacar que para Schacht a inflação era um efeito de fora para dentro do país, um movimento malevolamente forçado pelos aliados em episódios que contribuíram para a instauração da hiperinflação alemã, como a invasão do Vale do Ruhr e a cobrança das reparações (Schacht, 1956; 1999). 
necessidade de realizar uma reorganização das finanças alemãs, a qual se deu por meio do Plano Dawes. ${ }^{11}$

\section{Os planos econômicos e a crise de 1929 na Alemanha}

Em agosto de 1924, um novo acordo sobre o pagamento das reparações da Alemanha foi alcançado com o Plano Dawes. O principal objetivo desse plano era a retomada da confiança dos agentes econômicos dentro e fora da Alemanha, mantendo o capital alemão dentro do país, mas também atraindo capital estrangeiro, o que levou a capacidade de pagamento das reparações a níveis factíveis, haja vista que os pagamentos deveriam ser feitos em moeda alemã e esta estava ancorada em ouro (Eichengreen, 1992; Pocklington, 2017).

A Conferência Dawes se realizou em Paris (janeiro de 1924), tendo como presidente o general norte-americano Charles Dawes. No dia 23 de janeiro, Schacht prestou esclarecimentos aos membros da Conferência sobre a situação econômica da Alemanha [...]. O Plano Dawes foi assinado por ambas as partes em agosto de 1924, porém o total das reparações não foi fixado. O relatório final do Plano tinha os seguintes pontos principais: a) reforma monetária para estabilizar o marco (já realizada por Schacht); b) criação de novos impostos, para sanear o déficit público; c) revisão dos valores das reparações (o montante a ser pago anualmente seria de 1 bilhão de marcos-ouro nos quatro primeiros anos, e depois 2,5 bilhões pelos anos seguintes); d) empréstimos oferecidos pelos Estados Unidos; e) a França retiraria parte de suas tropas da Alemanha; f) reestruturação do Reichsbank, com a introdução de um grêmio fiscalizador. (Couto; Hackl, 2007, p. 324-325, grifo nosso)

A partir do Plano Dawes, foi minorada a enorme pressão que havia por parte dos países Aliados sobre a Alemanha, haja vista que os empréstimos norte-americanos facilitariam, em termos, o pagamento das reparações. Além disso, esses capitais americanos, de origem privada, possibilitaram investimentos municipais e estaduais o que alavancou

11 Essas perturbações internas na República de Weimar (1919-1933) só cessaram com um acordo entre industriais, governo alemão e Aliados, culminando na estabilização monetária alemã e na negociação do Plano Dawes, em 1924 (Schacht, 1931). 
atividades regionais na Alemanha. Entre 1924-1928, as exportações cresceram por volta de $80 \%$, enquanto o PIB cresceu mais de $30 \%$ e o desemprego caiu de 13,6\% para 8,4\% (Mazzucchelli, 2009). Com isso, o Plano Dawes possibilitou a reorganização das finanças alemãs, que, a partir de então, passavam a contar com supervisão externa:

Para também garantir a boa vontade da Alemanha de pagar as reparações, o Comitê Dawes colocara homens de confiança no Reichsbank e em outras organizações econômicas. Assim, os subordinados ao agente de reparações Parker Gilbert controlavam a solvência alemã. Tinham de cuidar para que a Alemanha pagasse suas reparações em dia. (Schacht, 1999, p. 294)

Portanto, mediante as questões mencionadas antes, do ponto de vista econômico, pode-se considerar que o Plano Dawes alcançou relativo sucesso na Alemanha entre 1924-1928. No entanto, do ponto de vista político, era um plano ambíguo, porque, embora tenha tido algum êxito, haja vista que os franceses desocuparam oVale do Ruhr em 1925, os fatores políticos externos, lê-se a supervisão norte-americana, levaram a discussão não mais para o quanto a Alemanha pagaria, mas, sim, se ela pagaria (Marks, 2003).

Cumpre ressaltar que o valor que o governo alemão considerava viável pagar era de uma quantia máxima de 20 bilhões de marcos-ouro, um sexto da quantia fixada no Ultimato de Londres. Para Schacht, esses 20 bilhões eram apropriados, pois a Alemanha já havia pagado muito mais do que lhe era viável, visto que ela entregou materiais e territórios aos países Aliados. Segundo o economista, no período compreendido entre 1919 e 1924, a Alemanha pagou o equivalente a 29 bilhões de marcos-ouro, cerca de 6,9 bilhões de dólares. ${ }^{12}$

Vamos então resumir o que a Alemanha pagou entre o Armistício e $1^{\circ}$ de setembro de 1924, quando o Plano Dawes entrou em vigor. Nesse período a Alemanha pagou: cerca de 2 bilhões de marcos (em dinheiro); 3 bilhões de pagamentos em mercadorias (gado, carvão, produtos manufaturados e

12 O valor de 6,9 bilhões de dólares foi calculado por meio da paridade do Rentenmark com o dólar, estabelecida em 1923 pelo Reichsbank da seguinte maneira: 1 marco-ouro = 1 Rentenmark; e 4,2 Rentenmarks $=1$ dólar; logo, 1 marco-ouro = 0,2380 dólares. 
materiais de construção); 9 bilhões pelo fato de ter sido obrigada a renunciar a todos os direitos e interesses dos seus cidadãos e empresas de serviço público; 6,5 bilhões por ter entregue materiais marítimos e rodoviários aos aliados; cerca de 3 bilhões por ter deixado para trás, em território inimigo, materiais não militares; e 5 bilhões em perda de propriedades estatais, para as quais nenhuma compensação foi feita a respeito das porções de terra do antigo território que foram cedidas. Até aqui somam-se 29 bilhões em perdas econômicas reais. (Schacht, 1931, p. 19-20, tradução nossa)

Naturalmente, a Comissão de Reparações não aceitou esses números ao registrar os créditos pagos na conta das reparações do Tratado de Versalhes, isso porque, com exceção dos pagamentos em dinheiro, os bens materiais (alimentos, carvão, produtos carboníferos, químicos e manufaturados, e material de construção) têm um valor diferente para quem paga e quem recebe. Em vista disso, entende-se que os valores pagos não foram devidamente contabilizados pela Comissão de Reparações, e sim considerados os mais baixos possíveis, a exemplo do carvão, que foi creditado a preço interno e não nas taxas do mercado internacional (Schacht, 1931). Um fator comum entre alemães e Aliados é que o primeiro pagamento das reparações, estabelecido na agenda de Londres (2 bilhões de marcos-ouro), foi feito integralmente em dinheiro. ${ }^{13}$

As disputas por território continuavam intensas mesmo no entreguerras, o que impactou diretamente o território do império alemão, que passou de $2.915 .069 \mathrm{~km}^{2}$ para apenas $540.000 \mathrm{~km}^{2}$. Nesse caso em específico, a Alemanha não somente "cedeu" todas as suas colônias no ultramar, mas foi desapossada de importantes territórios particularmente ricos em produtos agrícolas e minerais (Hobsbawm, 1995).

Sob o Tratado de paz de Versalhes, a Alemanha perdeu 10\% da sua população e 13,5\% do seu território anterior à guerra. Ela perdeu suas colônias, Alta Silésia, Alsácia-Lorena, distrito de Sarre, a maior parte do território de

13 Os demais pagamentos, datados para janeiro de 1922 e de 1923, foram muito aquém dos níveis fixados, o que levou à efetiva ocupação do Vale do Ruhr pelos franceses e belgas no dia 11 janeiro de 1923 (Maier, 1988, p. 242). Essa invasão ao coração industrial da Alemanha, somada a outras perdas territoriais, como da região do Sarre e da bacia do Reno, custou $80 \%$ de seus recursos de minério de ferro e $40 \%$ dos seus altos-fornos, o que reduziu drasticamente a base econômica alemã (Lehmann-Hasemeyer; Opitz, 2017). 
Posen e parte da Prússia Ocidental, Schleswig, Danzig, a parte báltica do território de Memel, os distritos fronteiriços ocidentais da Europa, entre outros territórios [...]. A partir de então a Alemanha passou a depender de um maior volume de importações de produtos alimentícios e matérias-primas, pois as regiões que foram perdidas eram particularmente as mais ricas do país no âmbito da agricultura e da indústria. A Alemanha perdeu $15 \%$ de suas terras cultiváveis e $75 \%$ de seus depósitos de minério de ferro. Sua capacidade de produção de ferro-gusa foi reduzida em $44 \%$, a de aço em 38\% e de carvão em 26\%. (Braun, 1990, p. 33)

Ainda assim, as perdas territoriais alemãs foram talvez maiores do que o esperado, mas não excepcionalmente exageradas se comparadas com os termos pretendidos pela Alemanha, se ela tivesse vencido a guerra. Também cabe dizer que durante a IGM o povo alemão não havia sofrido invasão territorial, o que contribui para que o seu dano material fosse praticamente inexistente.Visto que os alemães não sentiram os conflitos da guerra em seu solo, estes ficaram convencidos, por si mesmos, que não haviam perdido a guerra. Dessa forma, qualquer diminuição do seu território ou qualquer restrição deste era, por definição, considerada injusta (Marks, 2003; Moses, 2015).

Com isso, observa-se que em Versalhes, na Conferência da Paz, prevaleceu a máxima de Richelieu que diz que, em política, os fracos (e os vencidos) nunca têm razão. Certamente essa frase se aplica à IGM, principalmente por se tratar de uma guerra com mais de trinta beligerantes, na qual, entre os vencedores, estão grandes impérios como o britânico, o russo e o francês (Lousada, 2016). Não obstante, com o passar dos anos, a Alemanha conseguiu reverter o jogo, e ao longo dos desdobramentos dos pagamentos das reparações, ela foi dando passos rumo à paralisação desses pagamentos. Como se as dificuldas naturais do pós-guerra não fossem suficentes, as nações de todo o mundo tiveram que lidar com a crise. Em 1929, o colapso da bolsa não ficou restrito à periferia do sistema econômico mundial. Impactou diretamente as economias europeias industrializadas

A Alemanha, que já não estava em uma situação confortável devido às imposições do Tratado de Versalhes, também sentiu os impactos dessa grande recessão mundial. Os dados da Tabela 3 ilustram a situação da nação germânica no período entre 1928 e 1932. O primeiros combates à crise em questão se deram via forte austeridade fiscal, entretanto, tal 
estratégia se mostrou completamente ineficiente, mergulhando a economia alemã em um profunda crise (Nurkse, 1944). Em 1928 o desemprego na Alemanha não ultrpassava a casa dos 1,5 milhões de pessoas; já em 1932 salta para 5,6 milhões. No mesmo período, as exportações despencaram de 12,3 milhoes de RM (Rentenmark) para 5,7 milhões de RM.As importações seguiram o mesmo rítmo, caindo de 14 milhões de RM para 4,7 milhões de RM. Se considerarmos, através de número índice, a produção industrial alemã de 1928 representando 100, em 1932 encontramos o valor 58, ou seja, um abrupto apequenamento desta produção. Outrossim, também é possivel citar as vertiginosas quedas tanto do PNB (Produto Nacional Bruto) e da renda nacional que, neste período (19281932) foram de 89,5 milhões de RM para 57,6 milhões de RM, e de 75,4 milhões de RM para 45,2 milhões de RM, respectivamente (Overy, 1996; Mazzucchelli, 2009).

Tabela 3 - A Depressão na Alemanha (1928-1932)

\begin{tabular}{l|r|r|r|r|r}
\hline & $\mathbf{1 9 2 8}$ & $\mathbf{1 9 2 9}$ & $\mathbf{1 9 3 0}$ & $\mathbf{1 9 3 1}$ & $\mathbf{1 9 3 2}$ \\
\hline PNB (bilhões RM) & 89,5 & 89,7 & 83,9 & 70,4 & 57,6 \\
\hline Renda nacional (bilhões RM) & 75,4 & 76,0 & 70,2 & 57,5 & 45,2 \\
\hline Produção industrial (1928=100) & 100 & 100,1 & 87,0 & 70,1 & 58,0 \\
\hline Exportações (bilhões RM) & 12,3 & 13,5 & 12,0 & 9,6 & 5,7 \\
\hline Importações (bilhões RM) & 14,0 & 13,5 & 10,4 & 6,7 & 4,7 \\
\hline Desemprego (milhões) & 1,4 & 1,8 & 3,1 & 4,5 & 5,6 \\
\hline
\end{tabular}

Fonte: Mazzucchelli (2009, p. 149). Com base nos dados de Overy (1996, p. 14).

Assim, em meio ao caos do crash da bolsa de valores de Nova York, em 1929, era necessario um novo plano. A partir disso, foi criado o Plano Young que acabou se sobrepondo ao Plano Dawes. Isso aconteceu porque percebeu-se que as reparações não estavam sendo realmente pagas, pois a Alemanha quitava suas dívidas com o dinheiro emprestado, e não com os excedentes da balança comercial.

Diante de tal situação, foi convocada uma nova conferência, preparada durante o ano de 1928 e realizada em fevereiro de 1929, novamente em Paris. Presidida pelo financista norte-americano OwenYoung, a Conferência tinha duas questões importantes para serem resolvidas. A primeira referia-se ao valor que a Alemanha deveria pagar de reparações ao ano; a segunda dizia respeito à capacidade da Alemanha de transferir essa quantia em moeda 
estrangeira, de modo a não prejudicar o crescimento de sua economia. [...] Durante a Conferência Young, Schacht propôs a criação de um banco internacional que seria responsável pela distribuição dos pagamentos das reparações, mas que também fornecesse empréstimos aos países subdesenvolvidos para que pudessem se industrializar e, dessa forma, comprar os equipamentos da Alemanha. Com isso, o país teria divisas para pagar as reparações. (Couto; Hackl, 2007, p. 326-327)

Ademais, o Plano Dawes não havia fixado em específico nenhum montante a ser pago e o Plano Young veio suprir essa necessidade ao estabelecer que o montante total das reparações fosse de US\$26,36 bilhões, o equivalente a 121 bilhões de Reichsmark. De acordo com esse novo plano, os pagamentos seriam findados em 1988, de modo que as parcelas se dariam da seguinte maneira: "1,6 bilhões de Reichsmark deveriam ser pagos em janeiro de 1930 com anuidades aumentando para 2,3 bilhões de Reichsmark em 1987. A anuidade final a ser paga em 1988 seria de 898 milhões Reichsmark" (Braun, 1990, p. 46). Contudo, nenhum destes pagamentos chegou a acontecer.

Cabe aqui ressaltar que, na visão de Schacht, o Plano Young não era nem exequível enem necessário. ${ }^{14}$ Isso porque, segundo o presidente do Reichsbank, as reparações de guerra já estavam totalmente pagas, conforme demonstrou em uma prestação de contas que ele fez em 1931 nos Estados Unidos acerca do que entrou e saiu do país nos seis anos após a inflação (1924-1930). O economista também aproveitou o ensejo para falar abertamente sobre o quanto de propriedade alemã havia ficado com o exterior após a guerra, sem que isso fosse classificado como reparações, embora fosse; tratava-se de uma quantia de cerca de 148 bilhões de marcos-ouro, como consta na descrição a seguir: ${ }^{15}$

14 Embora se tenha chegado a um acordo comum, que efetivou a assinatura do Plano Young, ocorreram diversos manifestos contrários às negociações deste. O próprio Schacht, antes da assinatura desse novo plano, já demonstrava sua franca rejeição às reparações, tanto econômica quanto politicamente. No entanto, mesmo a contragosto, ele assinou os termos do plano, pois ponderou que a não assinatura com certeza teria agravado ainda mais os efeitos da crise econômica de 1929.

15 Não foram considerados os ônus com as tropas de ocupações e nem os custos de guerra, pois entende-se que os demais participantes da guerra também tiveram esses gastos. Além disso, ao converter esses 148 bilhões de marcos-ouro, usando a métrica já exposta anteriormente (1 marco-ouro = 0,2380 dólares), obtemos o valor de 35,2 bilhões de dólares. 
Durante os cinco anos em que o Plano Dawes estava funcionando, de setembro de 1924 a 31 de agosto de 1929, a Alemanha pagou cerca de 8 bilhões de marcos, aproximadamente metade em dinheiro e metade em material. Até a invasão do Ruhr, a Alemanha pagou indenizações no valor de 29 bilhões de marcos. [...] Além disso, a Alemanha perdeu 11 bilhões pela apreensão de propriedades privadas no exterior, e a perda das suas colônias soma um valor de 80 a 100 bilhões de marcos. Os próprios custos da guerra da Alemanha chegavam a cerca de 150 bilhões, a maioria dos quais, uma vez que dificilmente poderia ser criado novo capital durante a guerra, foi tirada diretamente do suprimento nacional de capital. As perdas da Alemanha pela inflação não podem ser contadas. E sobre essa economia nacional flagelada, o Plano Young ainda impôs uma nova carga de obrigações futuras, cujo valor presente é de 40 bilhões de marcos. (Schacht, 1931, p. 22, tradução nossa)

Dessa maneira, é possível traçar uma linha de conclusão lógica que inicia no Tratado de Versalhes em 1919, passa pelo Plano Dawes (1924) e chega ao Plano Young (1929), de modo que este foi a última grande emissão estrangeira em nome da Alemanha, a qual, quinze meses após seu nascimento, chegava ao seu fim (Eichengreen, 1992). Destarte, a Tabela 4 apresenta cronologicamente as medidas engendradas e implementadas no período compreendido entre 1919 e 1929:

Tabela 4 - Os desdobramentos dos pagamentos das reparações segundo os aliados e segundo a Alemanha (1919-1932) em bilhões de marcos

\begin{tabular}{l|l|l|l}
\hline \multicolumn{1}{c|}{ OCASIÃo } & Total A Pagar & $\begin{array}{c}\text { Pago SEgundo } \\
\text { OS Aliados }\end{array}$ & $\begin{array}{c}\text { PAgO Segundo } \\
\text { A Alemanha }\end{array}$ \\
\hline Junho de 1919 - Tratado de Versalhes & 20 bilhões ${ }^{1}$ & 8 bilhões & 111 bilhões $^{2}$ \\
\hline Abril de1921 - Comissão Reparação & 132 bilhões & - & 29 bilhões $^{3}$ \\
\hline Maiode1921 - Ultimato de Londres & 120 bilhões & 2 bilhões & - \\
\hline Agosto de1924 - Plano Dawes & $\begin{array}{l}\text { Não } \\
\text { estabelecido }\end{array}$ & 2 bilhões & 8 bilhões \\
\hline Julho de 1929 - Plano Young & 121 bilhões & - & - \\
\hline Total & - & 12 bilhões & 148 bilhões \\
\hline
\end{tabular}

Fonte: Schacht $(1931 ; 1999)$. Elaboração própria dos autores.

Nota 1: na ocasião do Tratado de Versalhes havia cláusulas a respeito da entrega de territórios no continente europeu e de colônias ultramarinas.

Nota 2: os alemães alegam que a apreensão das suas propriedades privadas no exterior equivale a um total de 11 bilhões de marcos, e suas colônias somam um valor de 100 bilhões de marcos.

Nota 3: a Alemanha alega que desses 29 bilhões, apenas 2 bilhões foram pagos em dinheiro, o restante se deu em mercadorias e materiais marítimos e rodoviários. 
Após o Plano Young houve outras questões econômicas de grande impacto no que tange à questão das reparações, como a grande depressão de 1929 e a declaração da moratória de Hoover (1931). Após mais de 10 anos de tentativas malsucedidas, a moratória de Hoover suspendeu tanto o pagamento das reparações quanto as dívidas de guerra interaliadas e, por isso, com fins de discutir o futuro dessas obrigações, fora convocada a Conferência de Laussane, na Suíça, em junho de 1932 (Schacht, 1956; Keynes, 2002).

Nessa conferência, a Alemanha conseguiu cancelar praticamente todos os seus compromissos de reparação, sendo que dos 120 bilhões prescritos em 1921, apenas 10\% havia sido pago, segundo os Aliados. Além disso, permaneceram pendentes mais de 20 bilhões pegos em empréstimos externos até o ano de 1930. Ou seja, os governos aliados embolsaram os dez a doze bilhões referentes às reparações, mas os investidores privados estrangeiros "perderam" o dinheiro emprestado à Alemanha (Marks, 2003). Portanto, assim estava selado o término das reparações, e Schacht enfim conseguiu seu grande feito: as reparações, já mortas, estavam agora efetivamente enterradas (Eichengreen, 1992; Schacht, 1931; 1999).

\section{Considerações finais}

Mesmo as grandes potências, França e Inglaterra, pertencentes ao bloco vencedor, saíram da guerra enfraquecidas em várias instâncias, em especial a França. O que se pode apontar é que alguns países se beneficiaram com a guerra, tal como os Estados Unidos. O sucesso americano tinha raízes fincadas no padrão-ouro, na sua capacidade de outorgar crédito ao mundo e nas facilidades produtivas, devido ao fato da IGM não se ter dado no perímetro do seu território.

Com cooperação norte-americana, outros países também reestabeleceram a sua paridade com o nobre metal dourado.A Alemanha foi um desses países, porque, assim como os demais países europeus, estava passando pelas turbulentas e penosas questões do pós-guerra (inflação, contas públicas, reinserção dos combatentes, reconstrução da produção industrial e agrícola, reparações, dívidas de guerra, entre outros).

A economia alemã, embora debilitada, conquistou paulatinamente 
certa autonomia, dada as políticas que Schacht foi tomando enquanto estava no comando das políticas ficais e monetárias do país. Um exemplo disso foi ter tido êxito na estabilização monetária do país sem o auxílio norte-americano. Esse feito foi resultado de uma ação conjunta de diversos fatores e circunstâncias, sendo a principal delas a firme disposição de Schacht para implementar políticas contracionistas. Foi por essa via que a Alemanha pôs fim à hiperinflação e reconstruiu sua credibilidade no cenário internacional.

Ao longo dessa reconstrução foi necessário o laço de cooperação internacional, como a que aconteceu entre Schacht e Montagu Norman, presidente do Banco Central da Inglaterra, para a fundação do Golddiskontbank no ano de 1924 (Pocklington, 2017). Outrossim, é importante observar que grande parte dos acontecimentos econômicos no mundo no período entre 1920 e 1930 teve influência dos quatro grandes banqueiros mundiais da época: Benjamin Strong, do Federal Reserve Bank de Nova York; Émile Moreau, do Banque de France; e os já citados Schacht e Norman.

Há autores que afirmam que esses homens padeciam da mesma falha: tinham apego à ortodoxia econômica. Exemplo disso ocorreu no crash da bolsa de Nova York, quando, ao invés de atuarem de maneira mais enfática para uma recuperação mais forte da economia mundial, esses banqueiros agiram de maneira contida e tardia, o que, segundo Liaquat Ahamed (2009), agravou a recessão.

Para Ahamed (2009), a obsessão dos Aliados para que a Alemanha pagasse montantes de reparações de guerra foi outro fator que acentuou a crise de 1929. Entretanto, cumpre mencionar que esse ponto estava fora da alçada desses quatro banqueiros, haja vista que eles possuíam posicionamentos distintos acerca dessa problemática.

Com o passar do tempo a cooperação entre esses grandes banqueiros foi se esvaindo, de modo que a falta de cooperação entre os bancos centrais minou a vigência do padrão-ouro. Segundo Marks (2003), isso aconteceu porque quando a responsabilidade com a cooperação internacional entrava em conflito com os objetivos nacionais, estes últimos prevaleciam.

Embora esse seja um posicionamento de praxe da política norte-americana, nota-se que essa também foi a conduta alemã.Afinal, as reparações de guerra, estipuladas na agenda de Londres em 1921, minguaram 
dez anos depois com a moratória de Hoover, em 1931. Segundo os franceses, isso aconteceu porque foram incrementados meios para protelar e não pagar o que fora calculado em reparação.

Tanto Schacht quanto Montagu eram incisivamente contrários ao tamanho das reparações exigidas. Não obstante, a maneira como se findou essa questão do pagamento das reparações, em 1932, na Conferência de Laussane, prejudicou os países a quem eram devidos tais proventos, os quais pouco ou nada receberam. Dentre eles, a França se destaca entre os países que mais passou por suplícios no período do entreguerras, tanto de ordem financeira quanto moral e civil.

A Alemanha, porém, também viveu suas mazelas na década de 1930, pois, com o fim da república de Weimar, voltou a sofrer por baixo crescimento, desemprego elevado, instabilidade monetária e déficits orçamentários. Tal cenário, segundo Straumann (2019), tornou-se um terreno fértil para a ascensão de Hitler e o Partido Nazista.

A Inglaterra também padeceu com a crise nas suas finanças públicas e na indústria nacional, tornando-se incapaz de impor sua hegemonia em âmbito mundial. Os Estados Unidos, por outro lado, em seu isolamento continental, colhiam os frutos da excepcional expansão econômica dos anos de 1920, oriunda da inabalável segurança em continuar progredindo com base nas próprias forças (Ferris, 1989).

Por último, no que tange à ascensão do nacional-socialismo antes citado, Schacht (1999) afirma que essa é uma questão de responsabilidade de todos os envolvidos nas relações econômicas do entreguerras. Ele que, em 6 de março de 1930, renunciou ao seu posto de presidente do Reichsbank, o fez de caso pensado, mas também um tanto desiludido. Este foi, na verdade, um sinal de desprendimento e de fidelidade às suas ideias. Um ato que contaria positivamente no futuro, pois ele não tardaria a voltar ao seu cargo. Afinal, a Alemanha não podia prescindir de seus serviços.

\section{Referências}

ABREU, Marcelo de Paiva. Keynes e as consequências econômicas da paz. In: KEYNES, J. M. As consequências econômicas da paz. Brasília/DF: Editora Universidade de Brasília, p. 9-30, 2002a. 
ABREU, Marcelo de Paiva. Keynes e as consequências econômicas da paz. Textos para discussão. Rio de Janeiro, n. 454, 2002b. Disponível em < http://www.dbd.puc-rio. br/depto_economia/td454.pdf>.Acesso em 5 julho 2019.

AHAMED, Liaquat. Lords of finance: the bankers who broke the world. New York: Penguin, 2009.

ARARIPE, Luiz de Alencar. Primeira Guerra Mundial. In: MAGNOLI, Demetrio (Org.). A história das guerras. São Paulo: Contexto, p. 219-353, 2006.

ARAÚJO, George. Uma revolução que não deve ser esquecida:Alemanha, 1918-1923. História Social. Campinas, v. 17, n. 2, p. 49-73, 2009. Disponível em <https://www. ifch.unicamp.br/ojs/index.php/rhs/article/viewFile/273/248>. Acesso em 5 julho 2019.

ARTHMAR, Rogério. Os Estados Unidos e a economia mundial no pós-Primeira Guerra.Estudos Históricos. Rio de Janeiro, v. 1, n.29, p. 97-117, 2002. Disponível em: <http://bibliotecadigital.fgv.br/ojs/index.php/reh/article/view/2156>.Acesso em 5 de julho de 2019.

ARTHMAR, Rogério. Política e economia na Terceira República francesa: Emile Moreau e a batalha do franco. Topoi. Rio de Janeiro, v. 12, n. 22, p. 187-208, 2011. Disponível em <http://www.scielo.br/pdf/topoi/v12n22/1518-3319-topoi-12-22-00187.pdf>. Acesso em 5 julho 2019.

BOEMEKE, Manfred; FELDMAN Gerald; GLASSER, Elisabeth (Org.). The Treaty of Versailles: a reassessment after 75 Years. Cambridge, New York, Melbourne: Cambridge University Press and The German Historical Institute, 1998.

BONNEFOUS, Édouard. Histoire politique de la Troisième République: Cartel des Gauches et Union Nationale (1924-1929). Paris: Presses Universitaires de France, 1960.

BECKER, Jean-Jacques. O Tratado de Versalhes. São Paulo: Editora Unesp, 2011.

BRAUN, Hans-Joachim. The german economy in the twentieth century. London: Ed. Routledge, 1990.

BRITISH COUNCIL. Remember the world as well as the war. Exter: University of Exeter, 2014. Disponível em <https://www.britishcouncil.org/sites/default/files/ remember-the-world-as-well-as-the-war-report.pdf $>$. Acesso 5 julho 2019.

COUTO, Joaquim Miguel; HACKL, Gilberto Melo. Hjalmar Schacht e a economia alemã (1920-1950). Economia e Sociedade. Campinas, v. 16, n. 3, p. 311-334, 2007. Disponível em <https://periodicos.sbu.unicamp.br/ojs/index.php/ecos/article/ view/8642810>. Acesso em 5 julho 2019.

COSTIGLIOLA, Frank. Awkward dominion: american economic political and cultural relations with Europe, 1919-1933. Ithaca: Cornell University Press, 1984.

DEHNE, Phillip. After the Great War: economic warfare and the promise of peace in Paris 1919. London: Bloomsbury Academic, 2019.

EICHENGREEN, Barry. Golden Fetters: the gold standard and the great depression, 1919-1939. New York: Oxford University Press, 1992.

FAVORATO, Diego Gonçalves; COLOMBO, Arthur Osvaldo. Keynes e Mantoux: distintas deduções sobre o Tratado de Versalhes. XI ENCONTRO INTERNA- 
CIONAL DA ASSOCIAÇÃO KEYNESIANA BRASILEIRA - DESAFIOS PARA A ECONOMIA BRASILEIRA: UMA PERSPECTIVA KEYNESIANA, 2019, Campinas. Anais do Encontro Internacional da Associação Keynesiana Brasileira. Campinas, 2019.

FERRIS, Jonh Robert. The elements of strategic policy, 1919-1926. In: FERRIS, Jonh Robert. The evolution of british strategic policy: 1919-1926. London: Ed. Palgrave Macmillan, p. 31-52, 1989.

FISK, Harvey Edward. The inter-ally debts: an analysis of war and post-war public finance, 1914-1923.New York: Bankers Trust Co., 1924.

HASTINGS, Max. Catástrofe - 1914: a Europa vai à guerra. Rio de Janeiro: Intrínseca, 2014.

HACKL, Gilberto Melo. Hjalmar Schacht e a economia alemã na primeira metade do século XX. Paraná: UEM, 2005 (Monografia de graduação em Ciências Econômicas da UEM). HOBSBAWM, Eric. A era dos impérios: 1875-1914. Rio de Janeiro: Paz e Terra, 1988.

HOBSBAWM, Eric. Era dos extremos: o breve século XX: 1914-191. São Paulo: Companhia das Letras, 1995.

KEYNES, John Maynard. As consequências econômicas da paz. São Paulo: Editora da Universidade de Brasília, 2002. Disponível em <http://funag.gov.br/biblioteca/ download/42As_Consequencias_Economicas_da_Paz.pdf $>$. Acesso em 5 julho 2019.

LEHMANN-HASEMEYER, Sibylle; OPITZ,Alexander. The value of political connections in the first german democracy: evidence from the Berlin stock exchange. Hohenheim discussion papers in business, economics and social sciences. Hohenheim, n. 24, p. 1-55, 2017. Disponível em < https://economics.unihohenheim.de/organisation/ publikation/the-value-of-political-connecions-in-the-first-german-democracy-evidence-from-the-berlin-stock-exchange>. Acesso em 5 julho 2019.

LEWIS, Arthur. Economic survey: 1919-1939. London: Routledge. 2003.

LOUSADA, Abílio Pires. As transformações e lições da Grande Guerra. Revista Militar. Lisboa,v. 68, n. 5, p. 389-428, 2016. Disponível em < https://www.revistamilitar.pt/ artigo/1122>. Acesso em 5 julho 2019.

MAIER, Charles. Recasting bourgeois Europe: stabilization in France, Germany, and Italy in the decade after World War I. Princeton: Princeton University Press, 1988.

MARKS, Sally. The illusion of peace: international relations in Europe, 1918-1933. New York: Macmillan, 2003.

MAZZUCCHELLI, Frederico. Os anos de chumbo: economia e política internacional no entreguerras. Campinas: UNESP-FACAMP, 2009.

MOULTON, Harold; LEWIS, Cleona. The french debt problem. New York: Macmillan, 1926.

MOSES, John. The war guilt question: a note on politics and historiography in the Weimar Republic. Australian Journal of Politics and History. Canberra, v. 61, n. 1, p. 128-134, 2015.

MOURÉ, Kenneth; MARTIN,Alexander. Crisis and renewal in France, 1918-1962. New York: Berghahn Books, 2002. 
NOGUEIRA, Flávio Schluckebier Pinto Saraiva. O papel dos EUA e da URSS na reconstrução do Estado alemão na República de Weimar. Revista de Economia Política e História Econômica. São Paulo, v. 7, n. 22, p.73-117,2010. Disponível em <http:// webcache.googleusercontent.com/search?q=cache:EC9XHjmJSPMJ:arquivos.info. ufrn.br/arquivos/2010248177090d5490878baedbea12cc/Revista_de_economia_ poltica_e_histria_econmica..pdf $+\& \mathrm{~cd}=3 \& \mathrm{hl}=\mathrm{pt}-\mathrm{BR} \& \mathrm{ct}=\mathrm{clnk} \& \mathrm{gl}=\mathrm{br}>$. Acesso em: 5 de julho de 2019.

NURKSE, Ragnar. International currency experience: Lessons of the Inter-War Period. Princeton, NJ: Princeton University Press for the League of Nations, 1944.

ORDE,Anne. British policy and european reconstruction after the First World War. Cambridge: Cambridge University Press, 1990.

OVERY, Richard James. The nazi economic recovery 1932-1938. Cambridge: Cambridge University Press, 1996.

POCKLINGTON, Jay. Behind the curtain of the old wizard: the german economic recovery under Hjalmar Schacht, 1933-1937. Berlim: Freie Universität Berlin, 2017 (Dissertação de mestrado em Economia).

REIS, Bruno Cardoso. Portugal e as pequenas potências na Grande Guerra de 1914-1918. Relações Internacionais. Lisboa, n. 42, p. 35-61, 2014. Disponível em <http://www. scielo.mec.pt/scielo.php?script=sci_arttext\&pid=S164591992014000200004>. Acesso em 5 julho 2019.

SCHACHT, Hjalmar. Confessions of the old wizard: the autobiography of Hjalmar Horace Greeley Schacht. Boston: Houghton Mifflin, 1956.

SCHACHT, Hjalmar. The end of reparations. New York: J. Cape \& H. Smith, 1931.

SCHACHT, Hjalmar. The magic of money. London: Oldbourne, 1967.

SCHACHT, Hjalmar. Setenta e seis anos de minha vida: a autobiografia do mago da economia alemã da República de Weimar ao III Reich. São Paulo: Editora 34, 1999.

STRAUMANN, Tobias. 1931: debt, crisis, and the rise of Hitler. Oxford: Oxford University Press, 2019. 
